\title{
Institutions, transaction costs, and entry mode choice in Eastern Europe
}

Meyer, Klaus E.

Document Version

Final published version

Publication date:

2000

License

CC BY-NC-ND

Citation for published version (APA):

Meyer, K. E. (2000). Institutions, transaction costs, and entry mode choice in Eastern Europe.

Link to publication in CBS Research Portal

\section{General rights}

Copyright and moral rights for the publications made accessible in the public portal are retained by the authors and/or other copyright owners and it is a condition of accessing publications that users recognise and abide by the legal requirements associated with these rights.

\section{Take down policy}

If you believe that this document breaches copyright please contact us (research.lib@cbs.dk) providing details, and we will remove access to the work immediately and investigate your claim. 


\section{CEES}

Working Paper No. 34

April 2000

Institutions, Transaction Costs, and Entry

Mode Choice in Eastern Europe

Klaus E. Meyer

Center for East European Studies

Copenhagen Business School 


\title{
Institutions, Transaction Costs, and Entry Mode Choice in Eastern Europe
}

Working Paper no. 34

April 2000

\author{
Klaus E Meyer \\ Copenhagen Business School
}

\begin{abstract}
The process of change from a central-plan system to a market economy generates institutions that are incomplete and unstable and in consequence generate high transaction costs. Multinational enterprises entering transition countries have to adapt their strategies to the local institutions and reduce exposure to highly imperfect markets. This paper analyzes how the costs of organizing business in transition environments influence entry mode choice. The empirical results show that host country institutions, specifically in the transition economies, impact on the choice of entry modes.
\end{abstract}

\section{Key words:}

Entry Mode Choice, Institutions, Transaction Costs, Transition Economies, Eastern Europe 


\section{INTRODUCTION}

Entry strategies of international business are adapted to the local institutions in the pertinent host economies (e.g. Oxley 1999, Peng 2000). Institutions are important for the functioning of a market economy as they constrain or facilitate business, and their establishment is an essential part of economic development and transition (e.g. Clague 1997, Harriss et al. 1995). To understand business strategies in emerging markets, it is necessary to analyze investment decisions in different institutional contexts, and the role and effects of institutions in reducing transaction costs (TC) in particular (Hoskisson et al. 2000). We focus on transition economies, where firms face unusually unstable and inconsistent institutions during the process of change from central-plan coordination to a market economy (Swaan1997b).

Multinational enterprises organize their cross-border operations as international trade, through contractual modes of coordination, or with equity investment as joint- or wholly-owned ventures. These modes provide varying degrees of control over the local operations, and have been analyzed with the TC approach (e.g. Anderson and Gatignon 1986, Hennart 1991) as well broader eclectic frameworks (Hill et al. 1990, Bell et al. 1997). This research has recently been extended to Central and Eastern Europe (CEE) (Brouthers et al. 1998, Meyer 1998), yet with few reflections on the transition-specific influences. We analyze the transition environments and their impact on entry mode choice, based on a unique survey of British and German businesses active in these economies. We argue, and show empirically, that entrants adust their mode choice to the specific TC arising due to different institutional frameworks.

The next section discusses the evolution of institutions in transition economies, their impact on TC, and consequently on entry mode choice. Section three introduces the methods of empirical analysis. Results are presented and interpreted in the section four. Section five concludes.

\section{INSTITUTIONS AND TRANSACTION COSTS IN TRANSITION ECONOMIES}

The essence of economic transition "from plan to market" (World Bank 1996) is the replacement of one coordination mechanism by another. The socialist regimes had strong vertical coordination of society and economy, but failed, among other reasons, because horizontal linkages were weak (Vlachoutsicos 1998) leading to high TC between enterprises within supply chains (e.g. Chikan 1996). 
Transition was to introduce more efficient coordination mechanisms. Yet, efficient markets depend on supporting institutions that can provide the (formal and informal) rules of the game of a market economy. Institutions reduce both transaction and information costs by reducing uncertainty and establishing a stable structure to facilitate interactions (North 1990). However, these were not in place when the socialist system disintegrated. With the dissolution of the plan, administrators became independent economic agents. They had to act on markets that did not yet exist; they lacked both the (tacit) knowledge on how to use the market mechanism and the market knowledge about potential partners and competitors. Without experience in a market context, agents had to identify potential types of business and preferences of potential business partners; and they had to learn to assess the composition of demand and supply, notably to estimate demand elasticity. Thus, agents engaged in considerable search processes to set up transactions and to find the right prices. All this increases TC of establishing new business relationships, and can inhibit many potential transactions (Swaan 1997b, Meyer 2001).

The rapid progress in establishing market-based institutions (Table 1), has reduced, but not eliminated, these high TC. Rapidly changing institutions may yield, at any point in time, inconsistency between institutions and uncertainty over future changes. Businesses react by relying on inherited systems of personal networks that served to overcome shortage under the central plan, and retained their importance as a coordination mechanism during transition. Network-based coordination has been observed throughout the region, e.g. in Hungary (Stark 1996, Whitley et al. 1996), the Czech Republic (Clark and Soulsby 1995), and Russia (Puffer 1996, Holden et al. 1998), where it is reenforced by cooperative value systems and traditions such as blat (Ledeneva 1999).

$* * * * *$

table 1 approximately here

$* * * * *$

Western businesses entering the transition economies also face high TC. This arises from lack of information about their partners; negotiations with partners inexperienced in business negotiations (Antal-Mokos 1998); unclear regulatory frameworks and an inexperienced bureaucracy (e.g. Thornton and Mikheeva 1996); the underdeveloped court system, and corruption. Among other institutions, the protection of intellectual property is weak, which as shown by Oxley (1999) 
increases investors preference for hierarchical modes. Similarly, full control may permit faster turnaround of acquired former state-owned enterprises (Aulakh and Kotabe 1997).

However, the costs of internal organization are also high. The whole economy of the central-plan regime was based on a hierarchy that established quantitative output targets for firms, with few incentives to provide quality and customer service. Workers and managers have thus developed considerable experience in shirking, and the underlying routines and attitudes persist in the transition (e.g. Sztompka 1993, Ledeneva 1999).

Moreover, the costs of establishing a wholly-owned operation are high. Until recently, acquisitions were only possible as part of the privatization process, which required complex negotiations with governmental authorities, management and work councils (e.g. Carlin et al. 1995). After the acquisition, post-socialist firms need considerable investment in enterprise restructuring and major changes in corporate strategy, organizational structure and culture (e.g. Newman 1998, Meyer and Møller 1998). Often, investors are also expected to assume financial and environmental liabilities of the acquired firm. Privatization-agencies often pursued 'staggered privatization' (Perotti and Guney 1993) offering initially only minority ownership, with an option to increase the share in equity later.

Greenfield investment may be too slow to achieve the desired strategic objectives, notably if firms pursue first-mover advantages (Meyer and Estrin 1999). They too face considerable establishment costs as local bureaucracies are slow, e.g. in approving acquisition of real estate. Moreover, greenfield projects may face more problems than modes involving a local partner when integrating into local business networks. This, however, is considered vital for business success, especially in Russia (e.g. Thornton and Mikheeva 1996, Puffer 1996).

Thus, the costs of setting up a fully-owned local operation in a transition economy are high. We expect establishment costs and costs of internal organization to outweigh the TC arising from weaker protection of property rights. The progress in economic transition and institution building reduces these costs, and facilitates higher degrees of internalization:

H1: $\quad$ Entrants are more likely to establish wholly-owned subsidiaries in advanced transition economies. 
Progress in transition brings the economic structure of host economies closer to Western European patterns. The structure of the economy in terms of, e.g., market size, competition and institutions is an important aspect of psychic distance (Nordström 1991). Operating in psychically distant countries, investors have to overcome the 'liability of foreignness' (Zaheer 1995): they have to gather information, train local staff and adapt management to the local environment. Moreover, risk assessment is hampered because the investor is not accustomed to the nature of many sources of risk and because of political influences on trans-border transactions (Caves 1996).

Psychic distance increases the cost of all forms of business, yet to different degrees (e.g. Oxley 1999). It reduces trust, and thus inhibits the formation of hierarchies (Root 1983, Shane 1994). At the same time, costs of organizational learning increase, which affects especially JVs and acquisitions (Kogut and Zander 1993, Barkema et al. 1996). The majority of prior studies ${ }^{1}$ suggest that greater the psychic distance, the greater would be the preference for external modes.

The psychic distance effect reinforces the effect of progress in transition as less reformed economies require more local adaptation. In addition, psychic distance is lower for source countries closer to the region: institutions in CEE converge with continental West European ones. Moreover, directly neighboring countries, like Germany, have a history of private and business contacts.

H2: $\quad$ Entrants originating in closer psychic proximity to transition economies are more likely to establish wholly-owned subsidiaries.

\section{Knowledge Transfer}

A prime theme of the $\mathrm{TC}$ and entry mode choice literature has been the market failure for information and knowledge transfer, be it due to information symmetries (Arrow 1971) or tacitness of the knowledge (Kogut and Zander 1993). Consequently, direct investment is frequently associated with the "public good character of knowledge within the firm" (Caves 1971:4), and the

\footnotetext{
Many empirical studies found that distance increases the likelihhod of low involvement modes (Davidson and McFetridge 1985, Gatignon and Anderson 1988, Gomes-Casseres 1989, Kogut and Singh 1988, Kim and Hwang 1992). Padmanabhan and Cho (1996) found an opposite effect, while Erramilli (1996) finds no significant effects. Bell et al. (1997) find a curve-linear effect suggesting that both very small and very large cultural distance increases the likelihood of JVs. Brouthers et al. (1998) argue that not only cultural distance but cultural attributes of host country (also see Shane 1994) and home country should be considered.
} 
transfer of brand-names as free-riders may otherwise degrade the quality of products (e.g. Anderson and Gatignon 1986).

In the transition economies, these issues are of particular concern because the institutional framework does not (yet) provide for efficient protection of property rights. Hence technologyintensive firms would prefer to internalize their transactions in high-tech goods and services. These firms are concerned about the transfer of technology-based capabilities, which includes production know-how, assessment of market opportunities for innovative products, feedback from sales to product development, as well as the training of sales and service personnel. In line with earlier research (e.g. Gatignon and Anderson 1988, Denekamp 1995, Hennart 1991) we thus propose:

H3a: Entrants that transfer technology are more likely to establish a wholly-owned subsidiary.

However, in CEE, technology transfer comes second to the transfer to modern managerial skills. Investors have to engage in management training and education in areas such as marketing, accounting and finance along with training in modern leadership skills (e.g. Child and Czegledy 1996). This transfer is necessary because management skills in the central plan system were fundamentally different (e.g. Puffer 1996). Yet, this requires transfer of tacit knowledge (Kogut 1996, Swaan 1997a), which according to Kogut and Zander $(1993,1996)$ cannot be transferred across markets as it requires personal interaction between transferor and recipient. We thus propose:

H3b: Entrants that build up local management capabilities are more likely to establish a whollyowned subsidiary.

\section{MethodologY}

\section{Modeling Organizational Modes}

Export and import are basic forms of international transactions as goods leave the sphere of influence of an exporting firm when handed over. The customer may organize logistics, distribution and possibly also other final stages of the product chain. The exporter may support local operations by training local partners but cannot control the use of goods and know-how transferred. 
International contracts can organize different types of transactions that transfer goods or services to a local partner in exchange for a fee or a share in revenues, e.g. licensing, franchising, subcontracting, and management contracts. Contracts may provide rights to constrain or monitor the partner. Notably, strong foreign partners can gain some degree of control over local partners in less advanced economies if the latter become dependent upon foreign inputs (e.g. Contractor and Kundu 1998).

A joint-venture (JV) places the local business unit under the joint control of the legally independent local and foreign partners (e.g. Harrigan 1988, Parkhe 1991, Ramamanathan et al. 1997). Through profit sharing, JVs create incentives to support the success of the venture, but they only partly eliminate the incentives to shirk on the partner. Moreover, JVs create complex governance problems between the partners. JVs are therefore avoided, unless TC in one or more of the markets concerned are very high and full internalization is not feasible (Hennart 1988, Buckley and Casson 1988).

Finally, the entrant can obtain full control over the local operation by establishing a whollyowned subsidiary or branch. This integrates the foreign operation into the multinational enterprise and eliminates the need to accommodate the interests of a local partner. As a trade-off, however, the investor then has to integrate a foreign business unit in its hierarchy and monitor foreign employees.

Most empirical studies analyze entry modes as dichotomous choices (e.g. Davidson and McFetridge 1985, Gomes-Casseres 1989, Hennart 1991). Gatignon and Anderson (1988), Kim and Hwang (1992) and Agarwal and Ramaswani (1992) use multinomial models to analyze the determinants of joint-ventures. Aulakh and Kotabe (1997) present an extended analysis of direct exports, wholly-owned subsidiaries and an intermediate construct. This paper analyzes the full range of entry modes: international trade, contractual arrangements, JVs and wholly-owned subsidiaries. The mode of business is a categorical variable defined as follows:

MODE $=3$ if the business relationship involves only trade

$=2$ if the business relationship involves contracts, but no direct investment

$=1$ if the firm has established a joint-venture (JV), but no wholly-owned operation $=0$ if the firm has established a wholly-owned subsidiary. 
The different modes are analyzed as alternatives without implicit order. In this, we follow theoretical arguments suggesting that these modes differ by more than one dimension. ${ }^{2}$ Buckley and Casson (1996) show that licensing would be preferable if markets are both highly volatile and large. It is less attractive if patent rights are poorly protected or if the value of the technology is highly uncertain. JVs are less attractive for business across high cultural distance because of coordination problems. Root (1987) located exports and wholly-owned subsidiaries at opposite corners of a box diagram with the dimensions 'risk' and 'control'. In his framework, contracts are characterized by zero risk and some degree of control. Also, the recent literature on strategic alliances (see Beamish and Killing 1997) commonly treats contractual modes underlying an alliance as distinct concepts rather than intermediates. Hence, intermediate forms may best minimize TC because they can effectively deal with specific kinds of TC.

\section{The Enterprise Survey}

The data for the analysis have been collected with a questionnaire survey of 677 West German and British companies in winter 1994/1995. The questionnaire was sent in German or English to key informants in the corporate headquarters to minimize information bias, after it had been tested in interviews and a pilot study (Meyer 1998). The companies were selected randomly from a database (Amadeus) of all firms in three broadly defined industries: food and beverages, chemicals, and engineering. 269 firms replied (39\%) and reported their business with five countries: Czech Republic, Hungary, Poland, Russia, and Rumania. The returned questionnaires include firms without business contacts in the region as, ex ante, it was not known whether or not the firms were active in CEE. The variation across various categories (e.g. size, industry, advertising expenditures) was low, suggesting that the non-response bias is small. From the survey, 656 observations of active business relationships of either mode in any of the five countries were obtained. Of these, 576 were used in the empirical analysis after eliminating missing values, providing a larger database than most empirical international business studies in transition economies.

\section{Variables}

2 Hennart (1993) modeled there modes along one dimension from markets to hierarchies. However, formal tests that can be obtained from the author confirm the appropriateness of the multinomial model. 
The progress of transition, which we expect to encourage wholly-owned operations (H1), is measured by a composite index TRANSITION based on the EBRD transition indices (Table 1). ${ }^{3}$ The differences of country of origin (H2) are proxied with a dummy variable GERMAN. Compared with British firms, German firms are geographically closer to CEE and benefit from personal relationships and traditionally more intensive trade relations.

The knowledge transfer $(\mathrm{H} 3 \mathrm{a}, \mathrm{H} 3 \mathrm{~b})$ is proxied by both firm and transaction level variables. $R \& D$ expenditures as percentage of turnover $(R \& D)$ captures technology intensity of the firm, as in prior research. Managerial knowledge is proxied by human capital intensity (HUMAN_CAPITAL), which we measure as personnel costs per employee. The survey provides information on the incidence of knowledge transfer, which is introduced as dummy variables T_TECHNOLOGY and T_MANAGMENT respectively. In addition, we presume that consumer goods manufacturers (dummy: CONSUM_GOODS) need to transfer more managerial know-how to establish new systems for marketing and distribution. They exchange sensitive marketing information with local marketing units, and monitor product quality to maintain brand reputation. For precise definitions of the variables refer to the appendix.

\section{Control Variables}

Prior research has pointed to the importance of organizational capabilities determining the (opportunity) costs of internalization (reviewed by Delios and Beamish 1999). We therefore include further firm-specific and transaction-specific variables as controls. Firms with related experiences and economies of scale and scope can organize a given transaction at lower costs. Large and experienced firms can share their resources, such as international management cadres and organizational capabilities, across operations. Hence, the marginal costs of an additional entry are lower. Size is proxied by firms' employment (SIZE), and global experience (GLOBAL) by the share of employment outside the home country. ${ }^{4}$

In addition to general capabilities of international business, certain capabilities are specific to the country or region of entry. This includes knowledge of the legal, social and economic

\footnotetext{
3 We use 1997 data for the empirical analysis as these are equally detailed but closer to the date of our survey than those reported in Table 1. The composite is the unweighted average of the 10 indices.

4 Measures for international experience have been included in prior studies including Teece (1977), Davidson and McFetridge (1985), Gatignon and Anderson (1988), Barkema et al. (1996), Kogut and Singh (1988).
} 
framework, contacts with local partners and government authorities, and product adaptation to local tastes, legal requirements and specific inputs. Established investors have acquired tacit knowledge through experiential learning (e.g. Barkema et al. 1996) and can better assess the investment risk (Aulakh and Kotabe 1997). Therefore, firms with experiences in the country are more capable of managing internalized business (Gomes-Casseres 1989, Hennart 1991).

In transition economies, learning on local business conditions is particularly important. A long-established presence improves the familiarity with culture-specific business practices and personal relationships, which are built over time and provide an important basis for business, especially in Russia (Ledeneva 1999, Holden et al. 1998). We measure this region-specific experience (REGION) by the share of turnover in CEE in total sales.

We moreover include an industry dummy for pharmaceuticals (PHARMA). In CEE, this industry requires lengthy approval procedures and is highly dependent on government policy since the health sector, its predominant customer, is a highly regulated service. Therefore, investment may be primarily determined by the outcomes of government-industry negotiations.

Furthermore we control for different international strategies pursued by the investors (cf. Hill et al. 1990). Different types of local operations create different cross-border interfaces, varying in their sensitivity to TC. Therefore, dummies are included for the types of transactions. ${ }^{5}$ Downstream, market-oriented business is used as base case, and dummies are added for upstream business (UPSTREAM) and for business with both upstream and downstream operations (UP\&DOWN). The different kinds of goods transferred are controlled for with dummies for final goods only (T_FINAL), final and other goods (T_FIN_ETAL), and for market-seeking business with only knowledge transfer (T_NONE). Furthermore, we include a control dummy for firms affiliated to non-European parents (NONEUR). Table 1 summarizes the hypotheses, proxies and the expected signs on 'wholly-owned subsidiary'.

$* * * * *$

Table 2 approximately here

$* * * * *$

I thank Mark Casson for pointing out that conventional analysis of transaction costs at firm level implicitly assumes that all firms engage in the same kind of transactions. Proper testing of TC theory therefore requires to control for different types business undertaken by these firms. 
Table 3 approximaltely here

$* * * * *$

\section{RESULTS}

Table 3 presents the regression results. The highly significant coefficients on TRANSITION support H1, which proposed that progress in building institutions increases investors' preference for internalization. Business in the advanced transition economies is more likely to be whollyowned, with small differences between other the modes. Thus, slow transition inhibits in particular the establishment of business under sole foreign ownership, which requires negotiations with privatization agencies, restructuring former state-owned enterprises, and operational management in the 'post-socialist' culture. Our results are opposite to Oxley's (1999) findings if we assume that progress in transition and protection of intellectual property rights are positively related. This suggests that a range of institutional factors influence mode choice and should be explored in greater detail in future research.

GERMAN firms are more likely to choose wholly-owned subsidiaries and have, relative to British firms, a particular aversion against contracts and, to a lesser extent, JVs. This supports H2, which proposed that wholly-owned operations are more feasible in nearby locations. Proximity and familiarity facilitate German entry into CEE without reliance on a local partner. Trade is less affected by psychic distance than cooperative modes because it requires less intensive interaction with local agents.

However, German and British firms differ by more than just distance to the transition economies. For instance, corporate culture, which is grounded in the culture the home environment, influences entry strategies in many ways (e.g. Brouthers et al. 1998). In a transition context, Barz (1999) observes that German firms take a more long-term perspective on their operations in Russia. This provides for an alternative explanation of the coefficients found for GERMAN.

The internalization incentives arising from control over know-how are partially supported as wholly-owned subsidiaries are preferred over trade. Yet, apart from managerial knowledge, it 
appears not to affect other choices. The coefficients on R\&D are correctly signed, ${ }^{6}$ but the actual transfer of technology is, surprisingly, more associated with JVs than with wholly-owned subsidiaries, though not significantly. In contrast to $\mathrm{H} 3 \mathrm{a}$, contracts, JVs and wholly-owned subsidiaries appear all suitable for the transfer of technology, despite their different control mechanisms.

This contrasts with the results for managerial knowledge $(\mathrm{H} 3 \mathrm{~b})$. The firm-level variables (HUMAN_CAPITAL, CONSUM_GOODS) are correctly signed, though not significant. Actual transfer of management know-how (T_MANAGMENT) is more likely to occur, as predicted, in wholly-owned subsidiaries and JVs, but not with contracts and trade. The transfer of management is the only information-related variable separating contractual cooperation and equity investment. Overall, the evidence for the link between of information intensity and higher degrees of internalization is weak. Knowledge intensive firms face the main differences between exports and the other modes.

More interesting are the differences between technological and managerial know-how. Our findings correspond with results by Ghemawar and Kennedy (1999) who found that relative to imports foreign investment into Poland is high in advertising intensive industries, but low in R\&D intensive industries. This reflects the absorptive capacity of local management (Lyles and Salk 1997): Eastern Europe has a solid basis in technological skills, but its human capital is weak in terms of managerial skills for a market economy (e.g. Swaan 1997a). Managerial knowledge transfer often involves tacit knowledge, which is more costly to transfer and therefore preferably internalized. This is of great importance for transition economies, though not necessarily elsewhere.

The control variables largely confirm expectations. Firms with extensive worldwide experience prefer wholly-owned subsidiaries, as indicated by the highly significant coefficients on GLOBAL. Their experience reduces costs of internal organization, and thus facilitates internalization. However, firm size (SIZE) favors wholly-owned subsidiaries only vis-a-vis contracts, indicating that contracts are used in particular by smaller firms. Region-specific

6 Note that pharmaceuticals companies significantly abstain from wholly-owned subsidiaries. The regressions were also run without the PHARMA dummy which frequently returned significant reverse coefficients of the R\&D variable. This can be explained by the behavior of pharmaceuticals companies, which enter CEE with relatively mature products. Excluding the PHARMA firms from the analysis yields results that are substantially identical to those presented in the text. 
experience (REGION) is correctly signed but insignificant. The NONEUR dummy shows a preference of firms with non-European parents for trade or wholly-owned subsidiaries. This may reflect that the scale of worldwide operations is not appropriately represented in the accounting data for the UK or German affiliate in the sample. The activity dummies were expected to indicate preference for internalization whenever they reflect more interactions between the parent firm and the country. The transfer of final goods (T_FIN_ETAL, T_FINAL), leads to more internalization as does the combination of business with both up- and downstream components (UP\&DOWN).

\section{Limitations}

We introduced the variable TRANSITION to proxy the variation of the institutional environment in the host economies. More detailed institutional variables would be desirable, yet we found a high correlation of different institutional and economic variables across the five countries that made it impossible to include several variables simultaneously. Future research should include more host countries to overcome this problem.

Moreover, the present sample is unbalanced as only few observations relate to contracts or JV. This explains some of the insignificant results for these modes. Last not least better proxies for the transfer of technology and management know-how would be necessary to explore the impact of different forms of knowledge transfer. Not anticipating dramatic differences, we collected only binary data on these.

\section{INTERPRETATION AND CONCLUSIONS}

The institutions of an economy determine the pattern of TC encountered by business. They thus select, and develop, coordination mechanisms that fit the environment. This is particularly evident in transition economies, where firms use, e.g., network-based strategies (e.g. Stark 1996), and barter (e.g. Seabright 2000). Foreign entrants too have to adjust to local conditions to accommodate high TC arising with volatile and inconsistent institutions. This is illustrated by the importance of environmental variables like 'progress in transition' and 'psychic distance'. Apparently, protection of intellectual property (Oxley 1999) is only one of several institutions of concern. 
This note reports a first empirical study of the link between institutions, transaction costs and entry mode choice in transition economies. Future research should refine both the theoretical and empirical analysis. Theoretical work should elaborate on the interaction between specific institutions, such as capital markets or protection of intellectual property, the TC in the pertinent markets, and the choice of business strategies minimizing these TC. Empirical studies should include more specific measures of institutions across a wider range of host countries. 


\section{Appendix: Definitions of the Independent Variables}

CONSUM_GOODS Dummy, taking the value of 1 if a consumer goods manufacturer, 0 otherwise.

GERMAN

Dummy, taking the value of 1 if the contacted firm is in Germany, 0 if it is in the UK.

GLOBAL

Percentage share of employment outside the home country in total employment, from (i) annual reports, (ii) Dun Bradstreet and Hoppensteadt directories, (iii) question 12.

HUMAN_CAPITAL_Ratio of personnel expenditures in $£$ sterling over employment, from (i) Amadeus database (ii) from annual reports or (iii) follow up questionnaire.

$\mathrm{R} \& \mathrm{D}$

Percentage ratio of research and development expenditures over turnover, from (i) annual reports, (ii) "The 1993 UK R\&D Scoreboard" (Company Reporting Limited), (iii) question 13 of the questionnaire, (iv) follow-up questionnaires, (v) predicted values of a regression equation using only variables not employed elsewhere in this research.

REGION Percentage share of turnover in CEE in total turnover of the firm. From (i) annual reports of the firm, (ii) question 12, (iii) follow-up questionnaires, (iv) from the questionnaire.

SIZE Number of employees of the firm, from (i) Fame and Amadeus database (ii) annual reports (iii) Dun Bradstreet and Hoppensteadt directories, (iv) follow-up questionnaires. For regression analysis divided by $10^{5}$.

T_MANAGMENT Dummy, taking the value of 1 if the respondent indicated transfer of managerial and or marketing know-how, zero otherwise.

T_TECHNOLOGY Dummy, taking the value of 1 if the respondent indicated transfer of patented and/or unprotected technological know-how, zero otherwise.

TRANSITION Unweighted average of ten indices presented by EBRD (1997) for the progress in economic transition. They cover aspects of enterprise reform, development of markets, financial institutions and the legal framework. 


\section{References:}

Agarwal, S. and S.N. Ramaswani. 1992: Choice of foreign market entry mode: impact of ownership, location and internalization factors, Journal of International Business Studies 23, p. 1-27.

Anderson, E.M. and H. Gatignon. 1986: Modes of foreign entry: A transaction costs analysis and propositions, Journal of International Business Studies, 17 (3), p. 1-26.

Antal-Mokos, Z. 1998. Privatisation, Politics, and Economic Performance in Hungary, Cambridge, CUP.

Arrow, K. J. 1971. Essays in the Theory of Risk Bearing, Chicago.

Aulakh, P.S. and M. Kotabe 1997. Antecedents and Performance of Channel Integration in Foreign Markets, Journal of International Business Studies 28, p. 145-175.

Barkema, H.G., J. Bell and J.M. Pennings 1996. Foreign Entry, Cultural Barriers and Learning, Strategic Management Journal 17, p. 151-166.

Barz, M. 1999. British and German MNCs in Russia and the FSU: Evidence from the Western Side, in: D.Dyker, ed.: Foreign Direct Investment and Technology Transfer in the Former Soviet Union, Cheltenham: Elgar.

Beamish, P.W. and J.P. Killing, eds. 1997. Cooperative strategies: North American perspectives, San Francisco: Lexington.

Bell, J., H.G. Barkema and A.Verbeke 1997. An Eclectic Model of the Choice between wholly-owned Subsidiaries and Joint-Ventures as Modes of Foreign Entry, in: P.W. Beamish and J.P. Killing, eds: Cooperative Strategies: European Perspectives, San Francisco: Lexington, p. 128-157.

Brouthers, K.D. , L.E. Brouthers and G.Nakos. 1998. National Cultural Influences on Central and Eastern European Entry Mode Selection, AIB Conference, Vienna.

Buckley, P. J. and M.C. Casson. 1988: A Theory of Cooperation in International Business, in: F.J. Contractor and P. Lorange, eds, Cooperative Strategies in International Business, San Francisco: Lexington, p. 31-54,

Buckley, P. J. and M.C. Casson. 1996: An Economic Model of International Joint Venture Strategy, Journal of International Business Studies 27, p. 849-876.

Carlin, W., J. van Reenen and T. Wolfe 1995. Enterprise Restructuring and Dynamism in Transition Economies, Economics of Transition 3, p. 427-458.

Caves, R. E. 1971: International corporations: The industrial economics of foreign investment, Economica 38, 1-27.

Caves, R.E. 1996. Multinational Enterprize and Economic Analysis, 2nd. ed., Cambridge: CUP.

Chikan, A. 1996. Consequences of Economic Transition on Logistics: The Case of Hungary, International Journal of Physical Distribution and Logistics Management 16, no. 1.

Child, J. and A.P. Czegledy 1996. Managerial Learning in the Transformation of Eastern Europe: Some Key Issues, Organization Studies 17, p. 167-180.

Clark, E. and A. Soulsby 1995. Transforming former state enterprises in the Czech Republic, Organization Studies 16, p. 215-242.

Clague, C. 1997. Institutions and economic development: Growth and governance in less-developed and post-socialist countries, Baltimore: Johns Hopkins University Press.

Contractor, F.J. and S. Kundu 1998. Modal choice in a world of alliances: Analyzing organizational forms in the international hotel dector, Journal of International Business Studies 29, p. 325-358.

Davidson, W.H. and Donald G. McFetridge 1985: Key Characteristics in the Choice of International Technology Transfer Mode, Journal of International Business Studies 16, no. 2, p. 5-21.

Delios, A. and P. Beamish 1999. Ownership strategy of Japanese firms: transactional, institutional and experience influences, Strategic Management Journal. 
Denekamp, J.G. 1995. Intangible Assets, Internalization and Foreign Direct Investment, Journal of International Business Studies 26, p. 493-504.

Erramilli, M.K. 1996. Nationality and Subsidiary Ownership Pattern in Multinational Corporations, Journal of International Business Studies 27, p. 225-248.

European Bank for Reconstruction and Development (EBRD) 1999. Transition Report 1999, London: EBRD.

Gatignon, H. and E. Anderson 1988: The Multinational Corporation Degree of Control over Subsidiaries: An Empirical Test of a Transaction Cost Explanation, Journal of Law, Economics and Organization 4, p. 305-366.

Ghemawat, P. and R.E. Kennedy 1999. Competitive Shocks and Industrial Structure: The Case of Polish Manufacturing, International Journal of Industrial Organization, Fall.

Gomes-Casseres, B. 1989: Ownership Structures of Foreign Subsidiaries. Theory and Evidence, Journal of Economic Behavior and Organization 11, p. 1-25.

Harrigan, K.R. 1988. Joint Ventures and Competitive Strategy, Strategic Management Journal 9, p. 141-158.

Harriss, J., J. Hunter and C.J. Lewis 1995. The new institutional economics and third world development, London: Routledge.

Hennart, J.-F. 1988: A transaction cost theory of equity joint-ventures, Strategic Management Journal 9, 361-374.

Hennart, J.-F. 1991: The Transaction Cost Theory of Joint-Ventures: an Empirical Study of Japanese Subsidiaries in the United States, Management Science 37, p. 483-97.

Hennart, J.-F. 1993: Explaining the Swollen Middle: Why most Transactions are a mix of 'Market' and 'Hierarchy', Organization Science 4, p. 529-547.

Hill, C.W.L., P. Hwang and W.C. Kim. 1990. An Eclectic Theory of the Choice of International Entry, Strategic Management Journal 11, p. 117-128.

Holden, N., C. Cooper and J. Carr 1998. Dealing with the New Russia: Management Cultures in Collision, Chichester: Wiley.

Hoskisson, R.E., L. Eden, C.M. Lau and M. Wright 2000. Strategy in Emerging Economies, Academy of Management Journal, forthcoming.

Kim, W.C. and P. Hwang. 1992: Global Strategy and Multinationals' Entry Mode Choice, Journal of International Business Studies 23, p. 29-53.

Kogut, B. 1996. Direct Investment, Experimentation, and Corporate Governance in Transition Economies, in: R. Frydman, C. W. Gray and A. Rapazynski (eds.): Corporate Governance in Central Europe and Russia, vol. 1, London and Budapest: Central European University Press, p. 293-332.

Kogut, B. and H. Singh 1988: The Effect of National Culture on the Choice of Entry Mode, Journal of International Business Studies 19, no. 3, p. 411-32.

Kogut, B. and U. Zander 1993: Knowledge of the Firm and the Evolutionary Theory of the Multinational Corporation, Journal of International Business Studies, p. 625-645.

Kogut, B. and U. Zander 1996: What do Firms Do? Coordination, Identity, and Learning, Organization Science 7, p. 502-518.

Ledeneva, A.V. 1998. Russia's Economy of Favours: Blat, Networking and Informal Exchange, Cambridge: CUP.

Lyles, M.A. and J.E. Salk 1996. Knowledge acquisition from Foreign Parents in International Joint Ventures: An Empirical Examination in the Hungarian Context, Journal of International Business Studies 27, p. 877-903.

Meyer, K.E. 1998. Direct Investment in Economies in Transition, Aldershot: Elgar.

Meyer, K.E. 2001. Transition Economies, in: T. Brewer \& A. Rugman, eds: Oxford Handbook of International Business, Oxford: OUP, forthcoming.

Meyer, K.E. and S. Estrin 1999. Brownfield Entry in Emerging Markets, 
Meyer,

$$
\text { 16, p. 411-421. }
$$

K

Denison, ed.:

Nordström, K. 1991.

Stockholm: Institute of International Business.

Institutions, Institutional Change and Economic Performance, Cambridge: CUP.

ey, Journal of Economic Behavior and Organization , , p. 283-310.

protection on the structure of inter-fi y

Padmanabhan, P. and K.R. Cho

firms, Management International Review 36, p. 45-63.

he,

Ventures,

18

Peng, M.W. 2000. Business Strategies in Transition Economies

Perotti, E.C. and S.E. Guney 1993. The structure of privatization plans. Financial Management 22, p. 84-98.

Business and management in Russia, Aldershot: Elgar.

$\mathrm{K}, \mathrm{A}$.

Cooperative Strategies: North American Perspectives, San Francisco: Lexington, p. 51-85.

Foreign Market Entry Strategies, New York: Amacon.

Entry Strategies for International Markets, Lexington, MA: Lexington Books.

Inside the multinationals: The economics of internal markets, London: Croom Helm.

The vanishing rouble: Barter and currency substitution in post-socialist societies

CUP, forthcoming.

Shane, S. 1994: The Effect of National Culture on the Choice between Licensing and Direct Investment, Management Journal 15, p. 627-642.

American Journal of Sociology $\quad$, 993-1027.

Swaan, W. 1997a. Tacit knowledge and post-socialist tran

Economic Systems

21, p. 375-379.

997b. Knowledge, transaction costs and the creation of markets in post-socialist economies, in: P.G. Hare and J. Davis, eds:

, Vol. II, London and New York: Routledge, p. 53-76.

Sztompka, P. 1993. Civilizational incompetence: The trap of post-communist societies, no. 2 , p. 85-95.

Teece, D. 1986. Transaction cost economics and the multinational enterprise,

Organisation 1, p. 21-45.

$\mathrm{J}$

alternatives to missing infrastructure,

38

V1

paper no. 120, William Davidson Institute, University of Michigan Business School, January.

Whitley, R., J. Henderson, L. Czaban and G. Lengyel 1996. Trust and contratucal relations in an emerging capitalis economy, Organization Studies 17, p. 397-420.

World development report: From plan to market, Oxford: Oxford University Press.

28, p. 341-363. 
Table 1: Progress of Transition

\begin{tabular}{|c|c|c|c|}
\hline & $\mathbf{C R}$ & PL & $\mathbf{R}$ \\
\hline \multirow[t]{10}{*}{ Large-scale privatization } & 4 & $3+$ & $3+$ \\
\hline & $4+$ & $4+$ & 4 \\
\hline & 3 & 3 & $2-$ \\
\hline & 3 & $3+$ & 3- \\
\hline & $4+$ & $4+$ & $2+$ \\
\hline & 3 & 3 & $2+$ \\
\hline & $3+$ & $3+$ & $2-$ \\
\hline & 3 & $3+$ & $2-$ \\
\hline & 3 & $3+$ & 3 \\
\hline & 3 & 4 & $3-$ \\
\hline
\end{tabular}

Countries: $\mathrm{CR}=$ Czech Republic, $\mathrm{HU}=$ Hungary, $\mathrm{PL}=$ Poland, $\mathrm{RO}=$ Romania, $\mathrm{R}=$ Russia

ablishing the relevant institutions. The classification is based on the EBRD's office of the chie economist.

EBRD 1999.

\begin{tabular}{|c|c|c|c|c|}
\hline Hypothesis & & referenc & & Mean (St.Dev.) \\
\hline & TRANSITION & & index & \\
\hline $\mathrm{H} 2$ & & WOS & & $.571(.495)$ \\
\hline & $R \& D$ & & percentage & \\
\hline & T_TECHNOLOGY & & dummy & \\
\hline $\mathrm{H} 3 \mathrm{~b}$ & & WOS & & $28,385(9,836)$ \\
\hline & & WOS & & $.335(.472)$ \\
\hline & & WOS & & $.410(.492)$ \\
\hline & SIZE & & employees, $10^{5}$ & \\
\hline & & WOS & & $.350(.284)$ \\
\hline & & WOS & & $.026(.026)$ \\
\hline & PHARMA & & dummy & \\
\hline & NONEUR & & dummy & \\
\hline & T_FIN_ETAL & & dummy & \\
\hline & T_FINAL & & dummy & \\
\hline & T_NONE & & dummy & \\
\hline & UPSTREAM & & dummy & \\
\hline & UP\&DOWN & & dummy & \\
\hline
\end{tabular}


Table 3: Multinomial Model

\begin{tabular}{|c|c|c|c|}
\hline & $\begin{array}{l}\text { Wholly-owned } \\
\text { vs. Joint-venture }\end{array}$ & $\begin{array}{c}\text { Wholly-owned } \\
\text { vs. Contracts }\end{array}$ & $\begin{array}{c}\text { Wholly-owned } \\
\text { vs. Trade }\end{array}$ \\
\hline ANSITION & $-2.650(0.675) * * * *$ & $-2.036(0.578) * * * *$ & $-2.692(0.521)^{* * * *}$ \\
\hline ERMAN & $-1.150(0.638)^{*}$ & $-2.899(0.540)^{* * * *}$ & $-0.847(0.504)^{*}$ \\
\hline$x \mathrm{D}$ & $-0.059(0.082)$ & $-0.045(0.056)$ & $-0.123(0.490)^{* *}$ \\
\hline TECHNOLOGY & $0.704(0.468)$ & $0.074(0.456)$ & $-1.630(0.506)^{* * * *}$ \\
\hline UMAN_CAPITAL & $-0.012(0.027)$ & $-0.011(0.024)$ & $-0.035(0.018)^{*}$ \\
\hline ONSUM_GOODS & $-0.139(0.473)$ & $-0.395(0.431)$ & $-0.746(0.384)^{*}$ \\
\hline _MANAGMENT & $0.034(0.500)$ & $-2.091(0.410) * * * *$ & $-3.222(0.387)^{* * * * *}$ \\
\hline $\mathrm{ZE}$ & $-1.017(1.088)$ & $-2.051(0.946)^{* *}$ & $-1.166(0.885)$ \\
\hline ILOBAL & $-2.728(0.890)^{* * * *}$ & $-2.324(0.733) * * * *$ & $-2.850(0.685)^{* * * *}$ \\
\hline EGION & $-11.064(8.874)$ & $-7.168(7.15)$ & $-9.634(6.232)$ \\
\hline HARMA & $0.241(1.019)$ & $1.369(0.790)^{*}$ & $2.994(0.688)^{* * * *}$ \\
\hline JONEUR & $-1.801(0.885)^{* *}$ & $-1.157(0.601)^{*}$ & $0.634(0.524)$ \\
\hline _FINAL & $-2.510(0.623)^{* * * *}$ & $-1.549(0.552)^{* * *}$ & $-1.283(0.524)^{* *}$ \\
\hline _FIN_ETAL & $-2.558(0.723) * * * *$ & $-2.703(0.707) * * * *$ & $-2.731(0.673) * * * *$ \\
\hline NONE & $-1.305(0.710)^{*}$ & $-2.330(0.784) * * * *$ & $-3.995(0.865)^{* * * *}$ \\
\hline JPSTREAM & $0.324(1.581)$ & $1.248(1.352)$ & $1.776(1.296)$ \\
\hline JP\&DOWN & $0.686(1.585)$ & $-0.871(1.383)$ & $-3.803(1.333)^{* * * *}$ \\
\hline Constant & $12.150(2.706) * * * *$ & $12.422(2.378) * * * *$ & $17.024(2.185)^{* * * *}$ \\
\hline nodel $\chi^{2}$ & $536.16(51)$ & correct predictions & $73.78 \%$ \\
\hline og-likelihood & -403.775 & $\rho$-statistic & $39.90 \%$ \\
\hline estr. log-likel. & -671.855 & $\chi^{2}$-test of IIA & $24,199(54)$ \\
\hline
\end{tabular}

Levels of significance: $*=10 \%, * *=5 \%, * * *=1 \%, * * * *=0,5 \%$

Negative sign $=$ preference for a wholly-owned subsidiary

\section{Frequencies of Actual and Predicted Outcomes}

Predicted

\begin{tabular}{lccclc|}
\hline \multicolumn{1}{c}{ Actual } & 0 & 1 & 2 & 3 & total \\
\hline 0 (Wholly-owned) & $\mathbf{1 1 8}$ & 1 & 5 & 27 & 151 \\
1 (JV) & 16 & $\mathbf{1 4}$ & 5 & 8 & 43 \\
2 (contract) & 15 & 3 & $\mathbf{2 1}$ & 45 & 84 \\
3 (trade) & 19 & 1 & 6 & $\mathbf{2 7 2}$ & 298 \\
\hline Total & 168 & 19 & 37 & 352 & 576 \\
\hline
\end{tabular}




\section{CEES Working Paper Series}

No., Date

No. 1

May 1996

No. 2

February 1997

No. 3

March 1997

No. 4

June 1997

No. 5

June 1997

No. 6

May 1997

No. 7

June 1997

No. 8

June 1997

No. 9

January 1998

No. 10

February 1998

No. 11

March 1998

No. 12

June 1998

No. 13

June 1998

No. 14

August 1998

No. 15

August 1998

No. 16

October 1998

No. 17 December 1998

No. 18

February 1999

No. 19

January 1999
Authors

Peter Nørgaard Pedersen

Saul Estrin \&

Klaus Meyer

Klaus Meyer

Snejina Michailova

Niels Mygind

Niels Mygind

Klaus Meyer

Snejina Michailova

Snejina Michailova \& Graham Hollinshead

Klaus Meyer \& Inger Bjerg Møller

Patrick Arens

Klaus Meyer

Klaus Meyer \& Christina Pind

Charalambos Vlachoutsicos

Derek Jones \& Niels Mygind

Klaus Meyer

Mår Klinge Jacobsen \& Klaus Meyer

Klaus Meyer \& Saul Estrin Entry Mode Choice in Emerging Markets:

Snejina Michailova \& Kari Organisation and Management Research in Transition Liuhto
Greenfield, Acquisition and Brownfield

The East European Business Environment: Opportunities and Tripwires for Foreign Investors

The Determinants of West-East Business: An Analysis of Ownership Advantages

Bulgaria in the Process of Systemic Transformation - An Overview

Different Paths of Transition in the Baltic

The Economic Performance of Employee-owned Enterprises in the Baltic Countries

Enterprise Transformation and Foreign Investment in Eastern Europe

Interface between Western and Russian Management Attitudes: Implications for Organizational Change

Developments in the Management of

Human Resources in Eastern Europe -

The Case of Bulgaria

Managing Deep Restructuring: Danish Experiences in Eastern Germany

Strategic Decision Making in the Transitional Economy of Romania: The Case of TAMIV S.A.

Foreign Direct Investment and the Emergence of Markets and Networks in Transition Economies

Ten Years of Foreign Direct Investment in the Former Soviet Union: A Survey with special Focus on Kazachstan

Russian Management: Value Systems and Inner Logic

Ownership Patterns and Dynamics in Privatized Firms in Transition Economies: Evidence from the Baltics

Entry into Transition Economies: Beyond Markets and Hierarchies

Opportunities in Russia: Internationalization of Danish and Austrian Businesses

Economies: Towards Improved Research Methodologies 
No. 20

February 1999

No. 21

March 1999

No. 22

April 1999

No. 23

May 1999

No. 24

July 1999

No. 25

July 1999

No. 26

Sept. 1999

No. 27

October 1999

No. 28

January 1999

No. 29

February 1999

No. 30

December 1999

No. 31

January 2000

No. 32

April 2000

No. 33

April 2000

No. 34

April 2000

No. 35

No. 36
Can-Seng Ooi \& Snejina Michailova

Panu Kalmi

Derek C. Jones \& Niels

Mygind

Derek C. Jones \& Niels

Mygind

Derek C. Jones \& Niels

Mygind

Derek C. Jones \& Niels

Mygind

Snejina Michailova

T. Mroczkowski, R.G. Linowes and A. Nowak

P. Kalmi, N. Mygind and E. Terk

Niels Mygind

Niels Mygind

Kenneth Husted and

Snejina Michailova

Klaus Meyer

Klaus Meyer

Klaus Meyer

Klaus Uhlenbruck and

Klaus Meyer

Enese Lieb-Doczy and

Klaus Meyer
Methodological Discipline in Comparing Emerging Economies

Employment and Share Trade Under Employee Share Ownership: An Application to Transition Economies

Employment and Share Trade underEmployee Share ownership: an Application to Transition Economies.

The Effects of Privatization on Productive

Efficiency: Evidence from the Baltic Republics

The Nature and Determinants of Ownership Changes after Privatization: Evidence from Estonia

Ownership and Productive Efficiency: Evidence from Estonia

Planning Change in Russia Companies with Foreign Participation

Differing Interpretations of Key Management Terms: Old versus New Poland

Ownership and Chief Executive Compensation: Evidence from Estonia

Enterprise Governance in Transition - A Stakeholder Perspective

Privatization, Governance and Restructuring of Enterprises in the Baltics

Knowledge Sharing in Russian Companies with Foreign Participation

International Business Research on Transition Economies

Enterprise Transformation as Coordination Game

Institutions, Transaction Costs, and Entry Mode Choice in Eastern Europe

for further information contact:

\section{Center for East European Studies}

Copenhagen Business School

Dalgas Have 15

DK-2000 Frederiksberg

Tel. (45) 38153030

Fax (45) 38153037

Most papers can be downloaded from the internet:

http://www.econ.cbs.dk/institutes/cees 